\title{
Reguleringen av polygame ekteskap i norsk rett
}

\author{
Tone Linn Wærstad
}

Tone Linn Wærstad er postdoktor ved Institutt for privatrett, UiO, der hun jobber med familierett, internasjonal privatrett og menneskerettigheter.

E-postadresse: t.1.warstad@jus.uio.no

\section{Adresse: Institutt for privatrett, Postboks 6706, St. Olavs plass, 0130 Oslo}

Denne artikkelen unders $\emptyset$ ker hvordan bigamiske ekteskap er behandlet i norsk rett.

Det finnes ingen samlet gjennomgang av hvordan disse ekteskapene er regulert $\mathrm{i}$

Norge, og en generell presentasjon av retten gis derfor først. Deretter gis en oversikt over det menneskerettslige rammeverket for reguleringen av polygame ekteskap.

Et hovedspørsmål er hvorvidt bigamiske ekteskap inngått i utlandet før noen av ektefellene hadde noen tilknytning til Norge, og der begge ekteskap fortsatt består, strider mot ordre public-reservasjonen i norsk rett. Enkelte ytterligere problemstillinger reiser seg, dels på grunn av manglende regulering, og dels på grunn av dårlig samsvar mellom ulike reguleringer i utlendingsretten og familieretten. Disse drøftes i et kvinne- og barneperspektiv.

Nøkkelord: polygami, bigami, ekteskap, anerkjennelse av utenlandske ekteskap, familieinnvandring, diskrimineringsvern, barnerett

\section{Innledning ${ }^{1}$}

Med økt innvandring til Norge fra land som tillater bigami, er det også kommet mennesker til Norge som er gift med flere. ${ }^{2}$ Disse bigamiske ekteskapene skaper utfordringer som vedrører

\footnotetext{
${ }^{1}$ Artikkelen tar blant annet sitt utgangspunkt i en utredning jeg avga 1. juni 2017 til Barne- og likestillingsdepartementet: «Utredning av ekteskapsloven $§ 18$ a - Barneekteskap og bigami», og videreutvikler noen av de resultatene jeg kom frem til der når det gjelder reguleringen i norsk familierett av bigamiske ekteskap der partene ikke har tilknytning til Norge ved vigselen. - Jeg ønsker å takke Thea Borkhus Gabrielsen og Oskar Otterstrøm for språkvask og korrektur. Jeg ønsker videre å takke anonyme fagfeller for konstruktive kommentarer.

${ }^{2}$ Dette fremkommer for eksempel i Barne-, ungdoms- og familiedirektoratet 2016. Ekteskapsloven $§ 18 \mathrm{a}$ :

Veileder for saksbehandling av enkeltsaker etter ekteskapsloven $\S 18 \mathrm{a}$ om anerkjennelse av ekteskap inngått i
} 
ulike deler av norsk rett, herunder familierett, strafferett, utlendingsrett og diskrimineringsrett. At det er en økning av disse ekteskapene som berøres av norsk rett, aktualiserer de norske reglene om bigami.

Et hovedspørsmål i denne artikkelen er hvorvidt bigamiske ekteskap inngått i utlandet før noen av ektefellene hadde noen tilknytning til Norge, og der begge ekteskap fortsatt består, strider mot ordre public-reservasjonen i norsk rett. Dette har vært ansett som usikkert, noe som skyldes et brokete og uklart rettskildebilde. Enkelte av de eldre kildene har mistet sin relevans som følge av samfunnsutviklingen. Samtidig har det kommet til nye kilder som ikke har fått tilstrekkelig oppmerksomhet.

Enkelte ytterligere problemstillinger reiser seg, dels på grunn av manglende regulering, og dels på grunn av dårlig samsvar mellom ulike reguleringer. Utlendingsrettens regulering synes å bryte med utgangspunktene i internasjonal privatrett på familierettens område. Det reiser seg også spørsmål knyttet til menneskerettslig regulering, som vedrører negative konsekvenser av reglene, spesielt for kvinner og barn. Disse behandles til slutt i artikkelen.

\section{Sentrale begreper}

\subsection{Bigami/polygami}

I den norske ekteskapsloven stadfestes det monogame prinsipp i § 4 ved at det slås fast at ingen kan inngå ekteskap så lenge et tidligere ekteskap består. ${ }^{3}$ Det er altså det etterfølgende ekteskapet som bestemmelsen retter seg mot: Forbudet mot bigami i norsk intern rett fører ikke til rettslige konsekvenser for det først inngåtte ekteskapet. ${ }^{4}$ Dette har betydning for forståelsen av bigami og reguleringen av slike ekteskap i norsk rett. En alminnelig forståelse av bigami er å være gift med to. Det er det etterfølgende ekteskapet som er det problematiske. Begrunnelsen for dette er åpenbar: Det første ekteskapet har ingen trekk i strid med norsk rettsorden. Det er et gyldig inngått ekteskap fra utlandet som skal anerkjennes etter norsk rett i tråd med el. § 18 a første ledd første punktum: «Et ekteskap som er inngått i utlandet, anerkjennes her i riket dersom ekteskapet er gyldig inngått i vigselslandet.» Betegnelsen «bigamisk ekteskap» betegner altså det andre, etterfølgende ekteskapet. Dette er også terminologien som følges i norsk familierettslig litteratur og som benyttes i denne artikkelen.

utlandet. Dette er også en problematikk norske ambassader møter på ulike måter, se for eksempel: Aftenposten (lest 15. desember 2017): https://www.aftenposten.no/norge/i/RkWRA/Ambassaden-slar-alarm-Norskpakistanske-menn-har-kone-nummer-to-i-Pakistan.

${ }^{3}$ Lov 4. juli $1991 \mathrm{nr} .47$ om ekteskap (heretter forkortet til ekteskapsloven eller el.).

${ }^{4}$ Se nærmere om dette i Thue 2002, s. 342. 
Når jeg legger vekt på dette, er det nettopp fordi å anlegge den alminnelige språklige forståelsen, der bigamisk ekteskap anses å inkludere også det første ekteskapet, vil lede til uheldige slutninger om disse ekteskapenes (det første og de senere ekteskapene) rettslige status. $^{5}$

Polygami betegner den situasjonen at en ektefelle er gift med flere. Det er en samlebetegnelse på tilfeller der en mann er gift med flere kvinner, såkalt polygni, og der en kvinne er gift med flere menn, det som kalles polyandri. ${ }^{6}$ Polyandri har tradisjonelt vært et svært sjeldent fenomen både faktisk og rettslig. ${ }^{7}$ Polygami som samlebetegnelse vil benyttes i artikkelen, også siden dette er et vanlig begrep når problemstillinger som gjelder flergifte, omhandles i internasjonal rett. Det er riktignok viktig å huske på at siden polyandri nesten ikke forekommer, i hvert fall ikke i lovlige former, vil polygami i praksis omhandle en situasjon der en mann er gift med flere kvinner.

\subsection{Ordre public-reservasjonen}

Ordre public-reservasjonen er et generelt unntak fra å anvende utenlandsk rett, eller å anerkjenne utenlandske rettsakter, når anvendelsen av fremmed rett vil føre til et resultat som strider sterkt med vår rettsfølelse. ${ }^{8}$ Ordre public-reservasjonen er et generelt rettslig prinsipp som har blitt kodifisert i en rekke ulike internasjonale konvensjoner og i nasjonal lovgivning. ${ }^{9}$ Ordre public-reservasjonen i el. § 18 a første ledd siste punktum er et slikt eksempel. Her stadfestes det at ekteskapet ikke anerkjennes «dersom dette åpenbart ville virke støtende på norsk rettsorden (ordre public)».

Hva som skal til for at noe skal anses å stride mot ordre public, kan riktignok ikke slås fast en gang for alle. Innholdet vil variere med den rettslige utviklingen og samfunnsutviklingen, og vil i siste omgang bero på en helhetsvurdering. ${ }^{10}$ Normalt vil det være hvorvidt resultatet av å anvende utenlandsk rett er i strid med ordre public, som det vil være aktuelt å undersøke. ${ }^{11}$ Men det kan også tenkes tilfeller der selv om resultatet i den enkelte sak ikke vil være støtende mot norsk rettsorden, vil det å anvende utenlandsk rett likevel være i strid med ordre

\footnotetext{
${ }^{5}$ Se den irske høyesterettsdommen H.A.H -v- S.A.A \& ors [2017] IESC 40 avsnitt 112-115 for en tilsvarende vurdering av status til første og andre ekteskap i irsk rett.

${ }^{6}$ Store norske leksikon (lest 30. november 2017): https://snl.no/polyandri

${ }^{7}$ Eriksen 1997, s. 113, Wikipedia (lest 30. november 2017): https://en.wikipedia.org/wiki/Polyandry og https://en.wikipedia.org/wiki/Legality_of_polygamy.

${ }^{8}$ Rt. 2009 s. 1537 avsnitt 37, se også Lundgaard (Gaarder) 2000, s. 101, Thue 2002 s. 176, Moss 1999, s. 132.

${ }^{9}$ Thue, 2002 s. 167. Cordes et al., 2010, s. 165.

${ }^{10}$ Se Thue 2002, s. 184 og 187-191, Frantzen 2002, s. 398.

11 Thue 2002, s. 183.
} 
public-reservasjonen. Dette vil typisk være der en anerkjennelse vil kunne få avledede og indirekte konsekvenser som er støtende mot grunnleggende prinsipper i norsk rett, eller dersom den utenlandske retten innebærer brudd på prosessuelle garantier som ikke kan godtas i vår rettsorden. ${ }^{12}$

\section{Rettslige utgangspunkter}

\subsection{Ekteskapsretten og strafferettens regulering av bigami}

Etter el. $\S 4$ er det ikke lov å inngå bigamiske ekteskap i Norge. Det å inngå et slikt ekteskap er belagt med straff etter strl. $§ 262 .{ }^{13}$ I den situasjon at noen rettsstridig skulle ha giftet seg bigamisk, følger det av el. § 24 første ledd: «Hver av ektefellene kan kreve ekteskapet oppløst dersom det er inngått i strid med $\S 3$ eller $\S 4$.» Videre har fylkesmannen etter andre ledd plikt til å reise sak for å få ekteskapet oppløst dersom ingen av ektefellene reiser slik sak. Fylkesmannen kan dersom sterke grunner taler for det, «likevel beslutte at sak ikke skal reises eller at saksanlegg skal utsettes».

I forarbeidene til § 24 omtales bare ekteskap som er inngått etter norsk rett. Ordlyden i bestemmelsen fremstår også som en rent internrettslig bestemmelse. Resultatet blir likevel at utenlandske bigamiske ekteskap som det kan reises sak om etter $\S 30 \mathrm{~b}$, vil rammes av $\S 24$. Grunnen til dette er at der ekteskapssak kan anlegges i Norge, jf. el. $\S 30$ b, vil alltid norsk rett anvendes, og dermed gjelder også $§ 24 .{ }^{14}$

Videre bestemmer el. $§ 18$ a andre ledd bokstav c at dersom minst en av partene var norsk statsborger eller fast bosatt her i riket på vigselstidspunktet, vil et ekteskap som er inngått i utlandet, ikke anerkjennes her i riket dersom en av partene allerede var gift. ${ }^{15}$ Formålet med bestemmelsen var å bekjempe tvangsekteskap i Norge. ${ }^{16}$ Et slikt ekteskap vil ikke anerkjennes som gyldig i norsk rett med mindre unntaket som følger i andre ledd, at ekteskapet etter begjæring fra begge og der sterke grunner foreligger, likevel kan anerkjennes. Forarbeidene gir anvisning på at unntaket om etterfølgende anerkjennelse skal være et snevert unntak. ${ }^{17}$ Praksis om slik etterfølgende anerkjennelse viser at det ikke vil være aktuelt å anerkjenne

\footnotetext{
${ }^{12}$ Cordero-Moss 2016, Thue 2002, s. 182-184 og s. 186, Wærstad 2016, s. 64.

${ }^{13}$ Lov 20. mai 2005 nr. 28 om straff (heretter forkortet til straffeloven eller strl.).

${ }^{14}$ Lødrup og Sverdrup, s. 91. Se nærmere om bestemmelsen under punkt 6.

${ }^{15}$ Bestemmelsen har denne ordlyden: «Et ekteskap som er inngått i utlandet, anerkjennes ikke her i riket dersom minst en av partene var norsk statsborger eller fast bosatt her i riket på vigselstidspunktet, og [...] en av partene allerede var gift.»

${ }^{16}$ Ot.prp. nr. 100 (2005-2006) s. 6.

17 Ot.prp. nr. 100 (2005-2006) s. 52.
} 
ekteskapet så lenge det er reelt bigamisk, det vil si at samlivet i begge ekteskap fortsatt består. ${ }^{18}$ Strafferettslig rammes ikke slike ekteskap av forbudet i strl. $§ 262$ så lenge det ikke også er straffbart etter loven i landet der ekteskapet er inngått, jf. strl. § 5 første ledd, nummer 1. Da det normalt ikke vil være mulig å inngå bigamiske ekteskap i land der dette er belagt med straff, får det norske straffebudet som forbyr bigamiske ekteskap, sjelden anvendelse i praksis

Etter å ha omtalt el. § 18 a andre ledd blir spørsmålet: Hva med de bigamiske ekteskapene som inngås før noen av partene hadde noen tilknytning til Norge, jf. el. § 18 a første ledd? Her er utgangspunktet, jf. første punktum, at «[e]t ekteskap som er inngått i utlandet, anerkjennes her i riket dersom ekteskapet er gyldig inngått i vigselslandet». Et bigamisk ekteskap vil altså i utgangspunktet anerkjennes med mindre unntaket om at det strider mot ordre publicreservasjonen i bestemmelsens fjerde punktum, kommer til anvendelse. Hvorvidt bigamiske ekteskap skal anses å være i strid med grunnleggende prinsipper i norsk rett, drøftes nedenfor. Et bigamisk ekteskap inngått i utlandet der ingen av partene hadde tilknytning til Norge på vigselstidspunktet, vil heller ikke være belagt med straff etter norsk rett ettersom det faller utenfor virkeområdet i strl. $§ 5$.

\subsection{Utlendingsrettens regulering av bigami}

Utgangspunktet i utlendingsretten når det gjelder polygame ekteskap der en person har inngått ekteskap med flere før vedkommende etablerer seg i Norge, er at kun ett av ekteskapene vil danne grunnlag for familieinnvandring til Norge. Utlendingsloven $\S 40$ syvende ledd første punktum lyder: «Dersom referansepersonen får opphold i riket etter å ha inngått ekteskap med flere, kan bare én av de ektede få oppholdstillatelse.» ${ }^{19}$

Det åpnes ikke for at to ektefeller skal kunne innvandre på bakgrunn av ekteskapet, men det skilles ikke mellom ekteskap nummer én og to i utlendingslovens forstand. Hensikten er ifølge forarbeidene å hindre polygame familier i å etablere seg i Norge. ${ }^{20}$

\footnotetext{
${ }^{18}$ Barne-, ungdoms- og familiedirektoratet 2016. Ekteskapsloven $\S 18 \mathrm{a}$ : Veileder for saksbehandling av enkeltsaker etter ekteskapsloven $\S 18$ a om anerkjennelse av ekteskap inngått i utlandet, s. 9.

${ }^{19}$ Lov 15. mai $2008 \mathrm{nr} .35$ om utlendingers adgang til riket og deres opphold her (heretter utlendingsloven eller utlendl.).

${ }^{20}$ Ot.prp. nr. 46 (1986-87) s. 60.
} 
En mann vil dermed kunne fortsette å være gift med kone nummer én i utlandet samtidig som han får anerkjent ekteskap nummer to i norsk rett, slik at kone nummer to vil kunne få oppholdstillatelse i tråd med utlendl. § 40 på bakgrunn av det bigamiske ekteskapet.

Flere andre bestemmelser er inntatt i utlendingsloven med det samme formålet om å hindre at polygame familier skal kunne etablere seg i Norge. Utlendl. $\S 44$ og 45 gjør unntak fra rett til oppholdstillatelse på andre grunnlag, der det ville føre til at polygame familieforhold ville etableres i Norge.

Utlendl. $\S 40$ og $\S \S 44$ og 45 tar sikte på å hindre polygame familier i å etablere seg i Norge, men det vil være muligheter for at dette likevel kan skje. Dette reiser igjen spørsmålet om hvilken status ekteskap nummer to i så fall vil ha etter norsk rett. Videre reiser det seg spørsmål til at det bigamiske ekteskapet stenger for familiegjenforening som ellers ville ha blitt gitt, noe som kan være problematisk i et menneskerettslig perspektiv.

4. Menneskerettslige rammer for regulering av polygame ekteskap

4.1.1. Innledning

Polygame ekteskap er regulert gjennom internasjonal rett som gjelder i Norge gjennom menneskerettsloven. ${ }^{21}$ Denne retten danner derfor rammer for hvordan polygame ekteskap kan reguleres i norsk rett. Et aktuelt spørsmål vil være polygame ekteskapsordningers status når det gjelder diskrimineringsvernet. Her vil FNs kvinnediskrimineringskonvensjon (KDK $)^{22}$ og FN-konvensjonen om sivile og politiske rettigheter $(\mathrm{SP})^{23}$ være spesielt relevante. Videre må det vurderes om polygame ekteskap nyter menneskerettslig vern som Norge er bundet av. Dette spørsmålet krever særlig undersøkelse av KDK og Den europeiske menneskerettighetskonvensjon. ${ }^{24}$

\subsubsection{Polygami og det internasjonale diskrimineringsvernet}

Flere internasjonale menneskerettighetskonvensjoner regulerer likestilling i ekteskapet. KDK art. 16 stadfester at «[k]onvensjonspartene skal treffe alle tiltak som er nødvendige for å avskaffe diskriminering av kvinner i alle saker som gjelder ekteskap og familieforhold». Det

\footnotetext{
${ }^{21}$ Lov 21. mai 1999 nr. 30 om styrking av menneskerettighetenes stilling i norsk rett (heretter forkortet til menneskerettsloven eller mrl.). Se nærmere om menneskerettighetenes stilling i norsk rett i Strand 2012, s. 8696.

${ }^{22}$ FNs konvensjon om avskaffelse av alle former for diskriminering av kvinner, 18. desember 1979 (heretter forkortet til KDK).

${ }^{23}$ Den internasjonale konvensjonen om sivile og politiske rettigheter, 16. desember 1966 (heretter forkortet SP).

${ }^{24}$ Den europeiske menneskerettskonvensjonen av 4. november 1950 (heretter forkortet EMK).
} 
kan raskt slås fast at en rettslig regulering av ekteskap der menn har anledning til å gifte seg med flere, men kvinner kun har anledning til å være gift med én, er direkte diskriminerende i strid med KDK art. 16 jf. art. 1. Spesielt vil art. 16 første ledd bokstav a («The same right to enter into marriage») og c («The same rights and responsibilities during marriage and at its dissolution») klart forby bigamiske ekteskapsordninger som skiller på antall ektefeller menn og kvinner kan ha.

Videre følger det indirekte av ordlyden i bestemmelsen at ekteskap med flere ektefeller enn to ikke er innenfor forståelsen av et ekteskap, ettersom ekteskap omtaler ektefellene som «begge ektefeller» og således er begrenset til to ektefeller. Polygame ekteskapsordninger vil dessuten være problematisk for oppfyllelsen av en rekke andre bestemmelser i konvensjonen, slik som forbudet mot strukturell diskriminering og kjønnsstereotypier i art. 2 f og 5 a, og de generelle reglene om statsforpliktelser $\mathrm{i}$ art. 2 og $3 .^{25}$

Kvinnediskrimineringskomiteen har i flere generelle kommentarer til statspartene behandlet polygami og slått fast de diskriminerende effekter bigamiske ekteskapsordninger og bigamiske ekteskap har for kvinner, jf. GC nr. 21, 27, 28, 29 og 31.

I generell anbefaling nr. 21, som var den første generelle kommentaren komiteen ga om kvinners rett til likestilling i ekteskap og familieliv, fastslår komiteen i avsnitt 14 at polygami bryter med kvinners rett til likestilling som er sikret gjennom konvensjonen: ${ }^{26}$

«Polygamous marriage contravenes a woman's right to equality with men, and can have such serious emotional and financial consequences for her and her dependents that such marriages ought to be discouraged and prohibited.»

Senere utdyper komiteen de diskriminerende og negative effekter polygame ekteskapsordninger har for kvinner. Det fastslås at polygami er i strid med kvinners og jenters verdighet, og bryter deres rettigheter og friheter, herunder deres diskrimineringsvern i

\footnotetext{
${ }^{25}$ Se nærmere om statsforpliktelsene i kvinnediskrimineringskomiteens generelle anbefaling nummer 28 (General recommendation No. 28 (2010), on the core obligations of States parties under article 2 of the Convention on the Elimination of All Forms of Discrimination against Women (UN Doc. CEDAW/C/GC/28, 2010). Begrepet «strukturell diskriminering» henspiller på strukturer som «lover, forskrifter, sedvane og praksis som innebærer diskriminering av kvinner», som nevnt i KDK artikkel 2 (f). Videre stadfester artikkel 5 a at statspartene skal treffe alle tiltak som er nødvendige «to modify the social and cultural patterns of conduct of men and women, with a view to achieving the elimination of prejudices and customary and all other practices which are based on the idea of the inferiority or the superiority of either of the sexes or on stereotyped roles for men and women». På denne bakgrunn er altså strukturell diskriminering tredelt: diskriminerende strukturer (artikkel 2 f), strukturer som er basert på et kjønnshierarki (artikkel 5 a, første alternativ), og strukturer som er basert på kjønnsstereotypier (artikkel 5 a, andre alternativ). Se nærmere om begrepets innhold i Wærstad 2017 b. ${ }^{26}$ General Recommendation 21 (1994), Equality in marriage and family relations (U.N. Doc. A/49/38 at 1).
} 
familien. ${ }^{27}$ Det påligger statspartene til KDK å motarbeide og forby polygami, og det kreves i avsnitt 28 aktiv handling fra statspartene for å bekjempe utbredelsen av bigamiske ekteskap. ${ }^{28}$

Menneskerettighetskomiteen anser det helt klart at polygami er i strid med SP, og at konvensjonen forplikter statene til å forby og bekjempe polygami. ${ }^{29}$ I GC 28 uttaler komiteen:

«It should also be noted that equality of treatment with regard to the right to marry implies that polygamy is incompatible with this principle. Polygamy violates the dignity of women. It is an inadmissible discrimination against women. Consequently, it should be definitely abolished wherever it continues to exist.» ${ }^{30}$

Situasjonen til kvinner som er i polygame ekteskap, er tatt opp av KDK-komiteen i GC 29 om $\emptyset$ konomisk likestilling mellom ektefeller i familielivet og ved skilsmisse: ${ }^{31}$

«States parties should take all legislative and policy measures needed to abolish polygamous marriages. Nevertheless, as stated by the Committee in its general recommendation No. 27, "polygamy is still practised in many States Parties, and many women are in polygamous unions". Accordingly, with regard to women in existing polygamous marriages, States parties should take the necessary measures to ensure the protection of the economic rights of women.»

Her viser komiteen den typiske tosidigheten som eksisterer med hensyn til spørsmålet om bigami og andre lignende spørsmål knyttet til diskriminering i ekteskapet; statspartene har en forpliktelse til å bekjempe bigamiske ekteskap, men har samtidig en forpliktelse til å ivareta enkelte rettigheter til de kvinnene som befinner seg i slike ekteskap. Dette vil typisk gjelde de $\emptyset$ konomiske rettsvirkningene som følger av ekteskap, slik som arv, foreldreskap og $\emptyset$ konomiske rettigheter i ekteskapet og ved dets avslutning. ${ }^{32}$

\footnotetext{
${ }^{27}$ Joint general recommendation No. 31 (2014), of the Committee on the Elimination of Discrimination against Women/general comment No. 18 of the Committee on the Rights of the Child on harmful practices (CEDAW/C/GC/31/CRC/C/GC/18, 2014.), punkt C.

${ }^{28}$ Kommentaren avsnitt 28.

${ }^{29}$ Human Rights Committee, General Comment 28, Equality of rights between men and women (article 3), (U.N. Doc. CCPR/C/21/Rev.1/Add.10), 2000.

${ }^{30}$ Kommentaren, avsnitt 24.

${ }^{31}$ General recommendation No. 29 (2013), on Article 16 of the Convention on the Elimination of all forms of Discrimination against Women (Economic consequences of marriage, family relations and their dissolution) (UN Doc. CEDAW/C/GC/29, 2013)

${ }^{32}$ Når det gjelder arv, tar komiteen opp dette direkte når det gjelder rettigheter til eldre kvinner etter konvensjonen, i generell anbefaling nummer 27 (General recommendation No. 27 on older women and protection of their human rights, CEDAW/C/GC/27). I avsnitt 53 anbefaler komiteen i tråd med konvensjonen at
} 
Det synes klart at EMK art. 14, jf. TP 7 art. 5, forbyr en ekteskapsordning som tillater flere ektefeller for menn og kun én ektefelle for kvinner. Ingen av statspartene tillater polygame ekteskap i intern rett, og spørsmål knyttet til polygame ekteskaps diskriminerende effekt for kvinner har derfor ikke vært direkte behandlet av EMD.

\subsubsection{Polygami og retten til familieliv}

EMK art. 8, som gjelder retten til respekt for privatliv og familieliv, har vært påberopt som vern for bigamiske ekteskap i flere saker for EMD.

Når det gjelder bigamiske ekteskap i intern rett, går det frem av EMD-praksis at disse ikke er vernet av art. 8. Allerede i saken James and Others $v$. the United Kingdom ble det stadfestet at det ikke påligger medlemsstatene noen forpliktelse til å tillate noen å være gift med flere i intern rett. ${ }^{33}$

I andre saker har det vært spørsmål om det påligger statene å anerkjenne bigamiske ekteskap som grunnlag for rett til familieinnvandring. At tillatelse ble nektet, ble ansett for å utgjøre en krenkelse av retten til familieliv etter art. $8 \mathrm{nr}$. 1, men ble likevel ansett som å oppfylle et legitimt formål i tråd med art. 8 nr. 2 som tillater unntak fra retten. ${ }^{34}$ Statene gis en vid skjønnsmargin til å bestemme hva som vil være i strid med det enkelte lands ordre public. I saken E.A. and A.A. v. The Netherlands uttales det: «[W]hen considering immigration on the basis of family ties, a Contracting State cannot be required under the Convention to give full recognition to polygamous marriages which are in conflict with their own legal order.» ${ }^{35}$

Spørsmålet om anerkjennelse av bigamiske ekteskap har ikke vært berørt i noen av rapportene fra Norge til de ulike menneskerettighetskomiteene, og heller ikke påkalt noen kommentarer fra komiteene.

\subsubsection{Konklusjon}

\footnotetext{
statspartene burde «ensure that upon the death of a polygamous husband, his estate is shared equally among his wives and their respective children».

${ }^{33}$ James and Others v. the United Kingdom of 21 February 1986, Series A no. 98. Alam and Khan v. The United Kingdom fra 1966 (application No. 2991 /661968 Y.B. Eur. Conv. H.R. 788 (Eur. Comm’n H.R.).

${ }^{34}$ E.A. and A.A. v. The Netherlands (Application No. 14501/89, Bibi v. United Kingdom (Application No. 19628/92).

${ }^{35}$ E.A. and A.A. v. The Netherlands (Application No. 14501/89), punkt 2. Bibi v. United Kingdom (Application No. 19628/92) stadfester dette.
} 
Det påligger ikke Norge noen forpliktelse til å gi opphold med grunnlag i familieinnvandring til mer enn én ektefelle. Dette er slått fast av EMD, og ingen andre relevante internasjonale kilder leder til et annet resultat.

Ekteskapsordninger som tillater menn å gifte seg med flere koner, men ikke lar kvinner gifte seg med flere menn, er direkte diskriminerende og i strid med menneskerettighetene. Det påligger statspartene å bekjempe utbredelsen av slike ekteskap.

Forpliktelsen er i hovedsak rettet mot å bekjempe at nye bigamiske ekteskap inngås. Når det gjelder ekteskap som allerede er inngått, oppstår det delvis motstridende forpliktelser. Samtidig som at statene er forpliktet til å bekjempe bigamiske ekteskap, er de også forpliktet til å ivareta de økonomiske rettighetene til kvinner som allerede befinner seg i slike ekteskap. Hva denne forpliktelsen nærmere går ut på når det gjelder ekteskap som beveger seg over landegrenser, er i liten grad utmeislet. Det at ingen av komiteene direkte har berørt tematikken og hvilken betydning dette skal ha for forpliktelser til for eksempel å bekjempe bigami som direkte diskriminerer kvinner, fører til usikkerhet med hensyn til statspartenes plikter. På den ene side må ikke reglene gå så langt i å anerkjenne slike ekteskap at det vil kunne støte an mot forpliktelsen til å bekjempe utbredelsen av bigami. På den annen side kan det reise problemer dersom nektelse av å gi rettsvirkninger til bigamiske ekteskap fører til økonomiske konsekvenser som vil ramme kvinner i disse ekteskapene hardt sammenlignet med kvinner i monogame ekteskap. Det som finnes av relevante menneskerettslige kilder, er i dag såpass sparsomt at det finnes et visst handlingsrom for myndighetene med hensyn til hvordan disse spørsmålene skal behandles. Men det påligger en generell forpliktelse om bevissthet knyttet til kvinners og barns rettigheter ved regulering og praksis knyttet til bigamiske ekteskap.

5. Hvorvidt bigamiske ekteskap strider mot ordre public-reservasjonen

5.1. Innledning

Bestemmelsen i el. § 18 a kom i 2007 og var en lovfesting av tidligere ulovfestet rett. Det er like fullt usikkert om bigamiske ekteskap skal sies å stride mot norsk ordre public. Dette skyldes nok at det har vært rettet lite oppmerksomhet rettet mot de spørsmål som reiser seg om bigamiske ekteskap når disse er blitt regulert i norsk rett. Slike spørsmål har i liten grad kommet opp i praksis. Dette skyldes dels at de går «under radaren» i behandlingen i norsk rett at disse ekteskapene er bigamiske, dels at det må antas å være ganske sjelden at menn som bor i Norge, vil være gift med to koner før han innvandret til Norge, og dels at det skal mye til for 
at begge konene skal klare å få oppholdstillatelse i Norge, slik at spørsmålet settes på spissen i en norsk sammenheng.

Det er likevel, etter mitt syn, gode grunner til å foreta en ny og oppdatert vurdering av dette spørsmålet. Dersom en polygam familie hadde etablert seg i Norge, ville det kunne reise prinsipielle spørsmål om dette er i tråd med grunnleggende prinsipper i norsk rett (ordre public). Å få frem argumenter for hvor grensen går for ordre public-reservasjonen, er derfor viktig for vurderingen av den samlede reguleringen av disse ekteskapene i norsk rett.

5.2. Nærmere om hvorvidt bigamiske ekteskap strider mot ordre public

Spørsmålet om polygame ekteskaps status er ikke behandlet i forarbeidene til el. § 18 a utover at det stadfestes at «[e]t i utlandet gyldig stiftet polygamt ekteskap er i utgangspunktet også gyldig etter norsk internasjonal privatrett, men rettstilstanden i norsk rett er noe uklar». ${ }^{36}$ Det stadfestes dermed at det er en uklar rettstilstand, uten at man går nærmere inn på hva uklarheten består i. Grunnen til at dette ikke drøftes nærmere, er antagelig at hovedpoenget med å innføre $§ 18$ a i ekteskapsloven var å forhindre tvangsekteskap, som ble regulert i bestemmelsens annet ledd. Det ville imidlertid fremstå som merkelig at ikke hovedregelen om forbud mot bigami, som til da hadde fulgt av ulovfestet rett, ikke ble tatt inn i loven. Denne ble derfor tatt inn som første ledd i bestemmelsen. ${ }^{37}$ Det har i teorien vært ansett som uklart hvorvidt bigamiske ekteskap skal anses å være i strid med ordre public-forbeholdet. ${ }^{38}{ }^{39}$ Det er kan hende karakteristisk for en prosess der en ulovfestet regel kodifiseres og får lovs form at problemstillinger knyttet til retten ikke kommer eksplisitt frem og drøftes.

Det foreligger to høyesterettsdommer om bigamiske ekteskap: Rt. 1977 s. 715 og Rt. 1983 s. 251. Dommene gjaldt begge en situasjon der ektemannen hadde inngått ekteskap nummer to etter at han hadde blitt bosatt i Norge. De belyser derfor ikke direkte hvordan ekteskap inngått før noen av partene hadde tilknytning til Norge, skal vurderes etter ordre public. Det kan dog muligens leses noe ut av den mer generelle uttalelsen til førstvoterende i 1977-dommen hvor han sier: «Jeg vil gjerne presisere at det avgjørende for meg er at et uomstøtelig polygamt

\footnotetext{
${ }^{36}$ Ot.prp. nr. 100 (2005-2006) s. 45.

${ }^{37}$ Ot.prp. nr. $100(2005-2006)$ s. 6 og 69.

38 Thue 2002, s. 343.

${ }^{39}$ Forarbeidene til ekteskapsloven av 1991 gir heller ingen redegjørelse for anerkjennelsesproblematikken. Da loven ble vedtatt og frem til vedtakelsen av $\S 18$ a, var den generelle regelen om anerkjennelse av et gyldig inngått ekteskap i utlandet med mindre det var ordre public-stridig, som nevnt, en ulovfestet regel, og tematikk om tvangsekteskap som var sentral da $\S 18$ a ble vedtatt, var ennå ikke satt på agendaen.
} 
ekteskap ikke lar seg innpasse i vårt rettssystem.» ${ }^{40}$ I 1983-dommen søkte ektefelle nummer to om separasjon, og fikk dette. Dette tyder i seg selv på at polygame ekteskap kunne anerkjennes, ettersom anerkjennelse er en forutsetning for å kunne få separasjon og skilsmisse. Resultatet i dommen må nok anses som å ha fremkommet under en helt konkret rimelighetsbedømmelse, der sentrale spørsmål vedrørende anerkjennelsesproblematikken ble oversett. ${ }^{41}$ Dommene er fra før dagens regulering i el. $\S \S 18$ a og 24, og ekteskap som sakene gjelder, ville i dag uansett blitt underlagt reglene i el. § 18 a andre ledd bokstav c, jf. siste punktum, og ikke $\S 18$ a første ledd som er hovedtema for denne artikkelen. ${ }^{42}$

Ett argument som har vært anført for å anerkjenne bigamiske ekteskap i Norge, er at betydningen ekteskap har i norsk rett og det norske samfunnet, har blitt svekket. Helge Johan Thue angir at det som taler for anerkjennelse, for det første er den $\emptyset$ kte internasjonaliseringen og økende respekt for andre kulturer, og for det andre «den relativisering av det 'kristne' monogame ekteskapet som har skjedd ved skilsmisser, samliv uten vigsel og partnerskap».43 Han gjennomgår rettstilstanden i andre monogami-land, og viser at de fleste av disse anerkjenner bigamiske ekteskap. Thue mener at dette peker mot en slik løsning også i norsk rett. Thues arbeid er fra over 15 år tilbake, og presentasjonen av andre lands behandling av utenlandske bigamiske ekteskap er nok foreldet i dag. Dessuten viser gjennomgangen kun hvorvidt bigamiske ekteskap ble ansett for å være i tråd med landets ordre public eller ikke. I og med at det ikke kommer frem hva som ligger under anerkjennelsesnormene, byr gjennomgangen i seg selv på få materielle argumenter når det gjelder anerkjennelsesproblematikken i norsk rett. Thue peker videre på at det er få slike saker, og at man allerede anerkjenner visse sekundære virkninger (slik som farskap, bidrag etc.) av disse ekteskapene. Sammenhengen mellom disse og anerkjennelse av ekteskapet tilsier at de bør anerkjennes.

Som Thue selv er inne på, men ikke ser på som noe avgjørende argument i vurderingen, peker likestillingshensynet $\mathrm{i}$ en annen retning enn de grunner Thue underbygger en anerkjennelsesnorm med: Respekt for andre kulturer er et relevant hensyn, men kan naturligvis ikke begrunne innpass av diskriminerende normer i norsk rett. Det at bigamiske

\footnotetext{
${ }^{40}$ Dommen s. 724.

${ }^{41}$ Se Thue 2002, s. 343-345, for en gjennomgang av dommene og kritikk av den uklarhet som kommer frem $\mathrm{i}$ 1983-dommen med hensyn til innholdet i ordre public-forbeholdet på dette området.

${ }^{42}$ Det er sparsomt med rettspraksis for $\emptyset$ vrig. Det er meg bekjent ingen underrettsdommer som direkte behandler spørsmålet om innholdet i ordre public-reservasjonen i el. $\S 18$ a første ledd med hensyn til bigamiske ekteskap.

43 Thue 2002, s. 347.
} 
ekteskap kun er åpent for menn og ikke kvinner, er direkte diskriminerende overfor kvinner. Det er godt dokumentert at polygami generelt setter kvinner i vanskelige situasjoner, for eksempel der ektemannen uten konens samtykke gifter seg på nytt og at hun dermed mister kontroll over sentrale elementer i sitt privatliv. ${ }^{44}$ Det kan også være at kvinner er sårbare for å presses inn i ekteskap som kone nummer to på grunn av for eksempel dårlig økonomi i hennes familie som ellers ville måttet brødfø henne. ${ }^{45}$

Dersom et ekteskap anses å være i strid med norsk ordre public, blir det ikke anerkjent, med den konsekvens at rettsvirkninger som ellers ville følge av ekteskapsloven, ikke vil inntreffe likevel. De rettslige konsekvensene av dette er ikke helt klare. Av spesiell betydning er de familieøkonomiske rettsvirkningene av ekteskapet. Dersom et bigamisk ekteskap anerkjennes, vil ekteskapet senere som den klare hovedregel oppløses etter el. § 24, som har de samme rettsvirkninger som en skilsmisse etter norsk rett. Etter norsk internasjonal privatrett vil boet i en slik situasjon (etter el. § 24) deles etter retten i ektefellenes første felles domisilland, som regelmessig vil være vigselslandet. ${ }^{46}$ Lovvalget om første felles domisilland vil i noen tilfeller stoppes av den generelle ordre public-reservasjonen dersom resultatet ville være støtende mot vår rettsprinsipper, for eksempel at det ville være diskriminerende overfor kvinnen. ${ }^{47}$ En ikkeanerkjennelse ville bety at ekteskapet ikke kan oppløses etter norsk rett, og dermed at man ikke vil få en deling av boet i tråd med ekteskapslovens regler. Hvorvidt det å underlegges rettsvirkningene etter $\S 24$ i praksis vil anses som en fordel for partene, er et spørsmål som kan tenkes å ha en viss betydning for ordre public-spørsmålet. De særegne spørsmålene som reiser seg her, er riktignok vanskelige å overskue virkningene av. Jeg forutsetter derfor, slik det er normalt i rettslitteraturen om dette spørsmålet, at en anerkjennelse av ekteskapet vil tjene ulike legitime hensyn til ektefellene. ${ }^{48}$ En slik tankegang er også det som ligger under kvinnekomiteens standpunkt om at de økonomiske rettighetene til kvinner i bigamiske ekteskap må ivaretas. Slike negative konsekvenser taler for ikke å benytte ordre publicreservasjonen.

Et annet moment i ordre public-vurderingen er at bigamiske ekteskap inngått rettsstridig $\mathrm{i}$ Norge - i den grad de finnes - er gyldige etter norsk rett. At ekteskapene i intern rett ikke blir

\footnotetext{
${ }^{44}$ Brooks 2009, s. 111.

${ }^{45}$ Det er en stor litteratur på dette området. Se for eksempel Blackburn 2004, kapittel 5, og WLUML 2006. Se Brooks 2009, s. 111-114 for videre referanser.

${ }^{46}$ Lovvalget følger av ulovfestet rett og er stadfestet i Rt.1995 s. 1415 (Joint Accounts).

${ }^{47}$ Wærstad 2017a, s. 285-299.

48 Thue 2002, s. 335, Frantzen 2007 s. 224, Holmøy et al. 2013, s. 117.
} 
ugyldige, er et sterkt argument for at utenlandske bigamiske ekteskap heller ikke kan anses å være i strid med norsk rettsorden: Det kan vanskelig sies at noe som er gyldig i intern rett, samtidig skal være i strid med norsk rett, slik ordre public-reservasjonen krever. ${ }^{49}$ Dette argumentet styrkes ytterligere av el. § 24 andre ledd andre punktum hvor det fremgår at når sterke grunner taler for det, kan fylkesmannen beslutte at sak om å oppløse et ekteskap inngått i strid med bigamiforbudet i $§ 4$ ikke skal reises. Unntaket benyttes riktignok kun i tilfeller der det første ekteskapet senere er avsluttet ved skilsmisse eller død, og får dermed mindre betydning for ekteskap der ektefeller fortsatt er gift med hverandre. ${ }^{50}$

Det at rettsstridig inngåtte ekteskap i intern rett ikke blir kjent ugyldige, er kommet inn i lovverket basert på en begrunnelse som ikke vil gjelde på samme måte for de utenlandske inngåtte ekteskapene. Videre er det noe uklart hvordan el. § 18 a og $§ 24$ skal forstås og avgrenses mot hverandre når det gjelder ekteskap inngått etter henholdsvis norsk og utenlandsk rett.

Endringen til at bigamiske ekteskap ikke lenger skulle være ugyldige, ble begrunnet med at det var få ekteskap det ville dreie seg om, at det var ulovlig å gifte seg når et ekteskap allerede besto, og at det ville forenkle ekteskapsloven. Oppløsning av ekteskapet ble ansett for å være en tilstrekkelig sanksjon mot det bigamiske ekteskapet. ${ }^{51}$

Ingen av disse grunnene knytter seg til situasjonen med anerkjennelse av utenlandske bigamiske ekteskap. Endringen er uttrykkelig begrunnet med at bigami både er en ekteskapshindring og belagt med straffansvar i norsk rett. Oppløsningsreaksjonen fremsto som en praktisk god løsning som samtidig ville oppfylle hensynet til å forenkle ekteskapsloven, som var et uttalt mål med den nye loven. I det hele tatt berører ikke Ekteskapslovutvalget utenlandske ekteskap og anerkjennelse av disse overhodet. Derfor er det ikke så mye å hente i denne argumentasjonen når innholdet i ordre public-reservasjonen i el. $\S$ 18 a skal fastlegges.

Et argument som taler for at bigamiske ekteskap skal anses å være i strid med ordre public, er at det er helt fremmed for norsk rett. Det monogame ekteskapet er en grunnleggende rettslig

\footnotetext{
${ }^{49}$ Se Frantzen 2002, s. 421, for en slik argumentasjon.

${ }^{50}$ NOU 1986: 2 Innstilling til ny ekteskapslov del I, pkt. 5.4.1 jf. pkt. 3.7.6 og 3.7.8.

${ }^{51}$ NOU 1986: 2 Innstilling til ny ekteskapslov, del I, pkt. 5.4.1 og 5.5, og Ot.prp. nr. 28 (1990-1991) Om lov om ekteskap, s. 27-29.
} 
konstruksjon i den norske ekteskapsretten. Dette kan illustreres gjennom denne uttalelsen til Ekteskapslovsutvalget:

«Norge hevder prinsippet om det monogame ekteskap, som de øvrige nordiske land og den kulturkrets vi tilhører. Forbudet i gjeldende lovs $§ 9$ mot at nytt ekteskap inngås så lenge tidligere ekteskap består, må selvsagt beholdes.

I praksis kan det oppstå særlige problemer når norske myndigheter ikke er kompetente til å behandle en separasjons- eller skilsmissesak, jf. kompetansereglene i tvistemålsloven $§ 419$ a. Et typisk eksempel er at en utlending kommer hit til landet og vil gifte seg her, men er tidligere gift. Det kan være praktisk umulig eller svært vanskelig å få oppløst ekteskapet i hjemlandet, og han/hun har ikke bodd lenge nok i Norge til å kunne få oppløst ekteskapet her. Utvalget finner det imidlertid klart at det ikke kan gjøres noe unntak fra bigamiforbudet av hensyn til slike forhold.»

Utlendingsloven $\S 40$ kan ved første øyekast fremstå som et argument for at bigamiske ekteskap ikke kan anses å være i strid med ordre public ettersom det er gitt valgfrihet om hvilken ektefelle som skal kunne få oppholdstillatelse basert på ekteskap med herboende, se punkt 3.3 ovenfor. Denne reguleringen i utlendingsretten taler for at bigamiske ekteskap der ingen av partene hadde tilknytning til Norge ved ekteskapsinngåelsen, ikke vil anses å være i strid med ordre public-reservasjonen.

På den annen side fremgår det av forarbeidene eksplisitt at slike ekteskap nettopp ikke vil være i tråd med grunnleggende prinsipper i norsk rett. I Ot.prp. 46 (1986-87) s. 60 står det:

«Det kan diskuteres i hvilken utstrekning vi i Norge skal innrette oss på å ta hensyn til innvandrernes egen kulturbakgrunn, og i hvilken utstrekning vi skal forlange at de følger norske normer. Justisdepartementet har antatt at den oppfatning av ekteskapet som vi har i vår vestlige kultur, må ses som en så vesentlig del av vår kulturbakgrunn at det må holdes fast på at denne skal legges til grunn.»

Som sitatet viser, er ikke aksepten som fremkommer for bigamiske ekteskap i utlendl. $\S 40$, ment å være noe argument for at bigamiske ekteskap skal anses å være i tråd med norsk ordre public. Hvorfor man så ikke har valgt å skille mellom første og andre ekteskap, kommer ikke frem av forarbeidene. Det kan tenkes at bevishensyn og praktiske hensyn ligger bak - at det fra land som godkjenner bigamiske ekteskap, har vært ansett for å være et generelt problem knyttet til notoritet rundt tidspunktet for ekteskapsinngåelser. 
Videre er det å inngå et bigamisk ekteskap i Norge, slik jeg redegjorde for innledningsvis, belagt med straff, jf. strl. § 262. Opprettholdelsen av bestemmelsen ble hovedsakelig begrunnet i markerings- og prevensjonshensyn. ${ }^{52}$ Dette taler for at bigamiske ekteskap strider mot vesentlige rettsgrunnsetninger i norsk rett.

\subsection{Oppsummering}

Det er flere trekk ved bigamiske ekteskap som er vanskelig å forene med norsk rett. Det er en helt fremmed konstruksjon i Norge at noen skal være gift med flere og at det derved kan knyttes rettsvirkninger til mer enn ett ekteskap for én person. Bigamiske ekteskap oppleves av de fleste som noe fremmed og negativt, og kan sies å stride mot den alminnelige rettsfølelse. At bigami i intern rett er forbudt og belagt med straff, støtter opp om et slikt argument. ${ }^{53}$

Videre er det problematisk at et bigamisk ekteskap som det er snakk om å anerkjenne i norsk rett, alltid vil være tuftet på en direkte diskriminerende ekteskapsordning der menn vil kunne ha flere koner, mens kvinner ikke vil kunne ha flere ektemenn. Fra et kvinneperspektiv er det klart at polygame ekteskapsordninger fører til brudd på kvinners rettigheter, se punkt 3.4.

Argumentene fra intern rett, jf. el. $\S 18$ a første ledd fjerde punktum og $\S 24$, gir et sammensatt og uklart bilde. Bestemmelsene ble vedtatt uten å ta stilling til hvorvidt bigamiske ekteskap som er inngått uten tilknytning til Norge på vigselstidspunktet, strider mot norsk ordre public. Bestemmelsen i $\S 24$ ble vedtatt med sikte på internt inngåtte bigamiske ekteskap, og begrunnet med at lovverket ellers har et sterkt vern mot at slike ekteskap i det hele tatt skal kunne forekomme. Det fremstår av lovforarbeidene som om spørsmålet om bestemmelsens mulige betydning for utenlandske ekteskap ikke har vært vurdert. At det heller ikke ble tatt stilling til spørsmålet ved lovbehandlingen av den nye $\S 18$ a, bidrar til den uklare rettstilstanden når det gjelder bigamiske ekteskap inngått i utlandet.

Det er gode grunner for ikke å anerkjenne bigamiske ekteskap i norsk rett basert på likestillingsargumenter og den fremmedartethet som bigamiske ekteskap må sies å ha i en norsk kontekst. Spørsmålet om anerkjennelse er fremdeles uavklart, og det er nok åpent hva

\footnotetext{
52 Ot.prp. nr. 22 (2008-09) Om lov om endringer i straffeloven 20. mai 2005 nr. 28 (siste delproposisjon sluttføring av spesiell del og tilpasning av annen lovgivning), punkt. 5.7.1.

${ }^{53}$ Se den irske høyesterettsdommen H.A.H -v- S.A.A \& ors [2017] IESC 40 avsnitt $112-115$ der lignende argumentasjon basert på irsk rett ble anvendt for å anse det andre ekteskapet for å være i strid med irsk ordre public.
} 
en domstol vil komme til i en konkret sak. Etter mitt syn taler de beste grunner for at anerkjennelse er i strid med ordre public.

6. Manglende samsvar mellom ulike rettsområder der polygame ekteskap reguleres, og veien videre

6.1. Behov for et bedre samsvar mellom el. $\S 18$ a og $\S 24$

Den rettslige sammenhengen mellom ordre public-reservasjonen i el. $\S 18$ a første ledd og $\S$ 24 må være slik at ekteskapene enten vil sies å være i strid med § 18 a og derfor ikke vil anerkjennes, og heller ikke kan oppløses etter $§ 24$, eller at de vil sies å være i tråd med ordre public-reservasjonen i $\S 18$ a og skal oppløses etter $\S 24$ med mindre unntaket i andre punktum kommer til anvendelse. ${ }^{54}$

I forarbeidene til el. $\S 24$ omtales som nevnt bare ekteskap som er inngått etter norsk rett. Ordlyden i bestemmelsen fremstår som en rent internrettslig bestemmelse. Et bigamisk ekteskap som er inngått i utlandet uten noen tilknytning til Norge, vil ikke være inngått i strid med den norske ekteskapsloven ettersom norsk lov ikke har jurisdiksjon over inngåelsen av ekteskapet. Resultatet blir likevel, som nevnt, at også utenlandske bigamiske ekteskap som det kan reises sak om etter $\S 30 \mathrm{~b}$, vil rammes av $\S 24 .{ }^{55}$ Her fremstår retten fragmentarisk, vanskelig tilgjengelig og lite gjennomtenkt fra lovgiverhold. Når det gjelder de ekteskap som er rettsstridig inngått i Norge, og derfor som den store hovedregel skal oppløses etter $\S 24$ andreledd, avveies de prinsipielle hensynene til de negative sidene ved bigami på den ene siden mot de mer praktiske hensyn som reiser seg til partene, på den annen. Det er tatt klart stilling til at bigami ikke er lov etter norsk rett, jf. el $\S 4$ og strl. § 262, men det er likevel slik at man av hensyn til partene anser det for tilstrekkelig å oppløse ekteskapet slik at det får de samme rettsvirkninger som skilsmisse, jf. el. $§ 24 .^{56}$

Denne avveiningen holder ikke stikk for de utenlandske inngåtte ekteskapene. Dersom disse blir ansett for å stride mot ordre public, vil ekteskapet etter norsk rett ikke anerkjennes, med den konsekvens at hensynene til partene ikke tilgodeses. ${ }^{57}$ Dersom ekteskapene derimot anerkjennes, vil de oppløses etter $\S 24$, men uten at det tas noen prinsipiell avstand fra bigami

\footnotetext{
${ }^{54}$ Holmøy et al. 2013, s.146. Holmøy et al. tenker særskilt på bestemmelsen i el. § 18 a andre ledd bokstav c, men avgrenser ikke til denne.

${ }^{55}$ Hva ekteskapssak er, er definert i el. § 25 a første ledd litra b: «Reglene i dette kapitlet kommer til anvendelse i saker: [...] om et ekteskap består eller ikke består, om oppløsning av ekteskap og om separasjon som reises for. domstolene (ekteskapssak).»

${ }^{56}$ NOU 1986: 2 Innstilling til ny ekteskapslov del I, punkt 5.3-5.6.

${ }^{57}$ Se punkt 5.2.
} 
slik det gjøres for de internt inngåtte ekteskapene. Dessuten er det noe usikkert hvilke konsekvenser det vil ha å oppløse ekteskapet, som skal gjøres etter retten i første felles domisilland. ${ }^{58}$

\subsection{Sammenhengen mellom utlendl. § 40 og ordre public-forbeholdet i el. § 18 a}

Det har vært et uttrykt mål for lovgiver å hindre at polygame familier etableres i Norge. Utlendl. § 40 syvende ledd første punktum stenger for å få familieinnvandring med mer enn én ektefelle ved at det fastlås at «[d]ersom referansepersonen får opphold i riket etter å ha inngått ekteskap med flere, kan bare én av de ektede få oppholdstillatelse». Det er riktignok ikke gitt noen begrunnelse, hverken i forarbeidene til gjeldende utlendingslov eller tidligere lover/forskrift der tilsvarende bestemmelse har vært hjemlet, for at det første ekteskapet ikke gis noen preferanse når det gjelder retten til familieinnvandring. ${ }^{59}$ Det slås kun fast at «en i praksis ikke har funnet grunn til å skille mellom den som er ektet først og den eller de som er ektet senere ${ }^{60}{ }^{60}$ Bestemmelsen ble videreført i ny utlendingslov, med en noe endret ordlyd, men i den hensikt å opprettholde det materielle innholdet i bestemmelsen. Dette fremkommer tydelig i NOU 2004: 20 kapittel 8.1.

Selv om det nok vil være usannsynlig, kan det likevel oppstå en situasjon der alle ektefeller i et polygamt ekteskap bosetter seg i Norge: En person har inngått ekteskap med flere før noen av partene har noen tilknytning til Norge. Ektemannen innvandrer så til Norge, og kone nummer to kommer som familieinnvandrer i tråd med utlendl. § 40. Kone nummer én kommer så til landet på selvstendig grunnlag, typisk ved at hun får innvilget asyl. ${ }^{61}$ I denne situasjonen vil ekteskap nummer to være godkjent av norske myndigheter i tråd med en lovordlyd der det fra lovgivers side er bevisst valgt å ikke skille mellom første og andre ekteskap med hensyn til anerkjennelse. Det første ekteskapet kan ikke angripes etter norske regler, for det har ingen trekk som er støtende mot norsk rettsorden.

Spørsmålet blir så hva slags status ekteskap nummer to nå får etter at begge ektefeller er bosatt i Norge. For det første blir det et spørsmål etter el. § 18 a første ledd: Skal det anses å

\footnotetext{
${ }^{58}$ Jf. Rt 1995 s. 1415 (Joint Accounts). Se punkt 5.2.

${ }^{59}$ Dagens regulering i utlendl. $\S 40$ syvende ledd er en fortsettelse av regulering i den opphevede utlendingsforskriften 21 . desember $1990 \S 23$. Forarbeidene til begge bestemmelser er derfor relevante. Reglene diskuteres i Ot.prp. nr. 46 (1986-87) s. 60, og i NOU 2004: 20 Ny utlendingslov og i Ot.prp. nr.75 (2006-2007) Om lov om utlendingers adgang til riket og deres opphold her (utlendingsloven), s. 423-424.

${ }^{60}$ Ot.prp. nr. 46 (1986-87) side 60.

${ }^{61}$ Som vi så i punkt 3.3, vil hun normalt ikke kunne komme som familieinnvandrer til eventuelle barn hun har med ektemannen som bor i Norge, for det stenger normalt utlendl. §§ 44 (2) og 45 (2) for. Problemstillinger som reiser seg angående disse bestemmelsene, kommer jeg tilbake til nedenfor.
} 
være i strid med ordre public-reservasjonen? Dersom ekteskapet anses å gå klar av ordre public-reservasjonen, skal det oppløses i tråd med el. § 24. Reglene reiser spørsmål ved om valgfriheten som gis etter utlendl. § 40, er hensiktsmessig, når ekteskap nummer to senere likevel kan møtes med manglende anerkjennelse eller oppløsningskrav etter reglene i ekteskapsloven.

I utgangspunktet er det uklart om ekteskapet vil anses å være i strid med ordre public. Vurderingen blir imidlertid enda vanskeligere ved at ekteskapet allerede eksplisitt er vurdert og anerkjent av norske myndigheter i forbindelse med oppholdstillatelsen som er gitt med hjemmel i utlendl. § 40 syvende ledd første punktum. Det gis ikke noen begrunnelse for hvorfor man ikke skal skille mellom det første og andre ekteskapet. Det slås bare fast at den kone som først søker om oppholdstillatelse, vil få tillatelse. ${ }^{62}$

Det er altså et manglende samsvar mellom de ulike delene av retten, uten noen klar begrunnelse. Det er naturlig at det som anses som grunnleggende utgangspunkter for retten, ikke fravikes uten begrunnelse når ekteskapene skal reguleres på et annet rettsområde. Den løsningen som er valgt i utlendingsloven, ser bort fra preferansen for det første ekteskapet, uten at det gis noen begrunnelse. ${ }^{63}$

Reguleringen er videre uheldig siden den skaper ytterligere usikkerhet rundt innholdet i ordre public-reservasjonen i el. $\S 18$ a første ledd fjerde punktum, uten at det er tiltenkt bestemmelsen å ha en slik innvirkning. Dessuten vil selve anerkjennelsen av det bigamiske ekteskapet i tråd med utlendl. $\S 40$ være både en formell og reell anerkjennelse av ekteskapet i norsk rett, som partene da vil ha grunn til å innrette seg etter og som fortjener å opprettholdes i norsk rett. Problemet settes riktignok først på spissen dersom den første konen skulle få opphold i Norge på selvstendig grunnlag. Da følger det uansett av § 24 andre ledd, jf. § 30 b, at ekteskap nummer to må oppløses. Det er nok grunn til å anta at det sjelden vil komme frem for UDI hvorvidt ekteskapet er bigamisk. Videre er det grunn til å tro at selv om det skulle komme frem at det er ekteskap nummer to som det søkes om familieinnvandring for, vil det bli godtatt. Preferansen for det første ekteskapet, som overses i utlendl. § 40, kommer tilbake i intern rett. Reglene savner harmonisering, og dette fører til et uheldig resultat: Hensynet til kvinners diskrimineringsvern som ivaretas av reglene i ekteskapsloven og straffeloven, mangler i utlendingsloven. Partene som har innrettet seg etter at ekteskapet er anerkjent og har

\footnotetext{
62 Ot.prp. nr. 46 (1986-87) s. 60.

${ }^{63}$ Thue 2002, s. 345, er også kritisk til bestemmelsen: «[Mannen] gies her et valgprivilegium som han ikke engang har etter islamsk rett. En slik valgfrihet lar seg ikke rettslig begrunne.»
} 
dannet grunnlag for en gyldig familieinnvandring til Norge, kan bli stående i en situasjon der ekteskapet likevel ikke anerkjennes etter el $§ 18$ a, eventuelt oppløses etter el. $§ 24$ annet ledd.

Det bør derfor vurderes om det skal stilles krav til at det første ekteskapet prioriteres foran det andre ekteskapet for at familieinnvandring basert på ekteskap skal innvilges. Dersom en annen ektefelle skulle komme til landet og vise seg å være ektefelle nummer én, vil ansvaret for familieinnvandring for kone nummer to ligge hos partene til søknaden, og ikke hos norske myndigheter slik det er i dag. En situasjon hvor kone nummer én er innvilget familieinnvandring og kone nummer to siden får oppholdstillatelse på selvstendig grunnlag, vil ikke skape de samme rettslige problemene ettersom det andre ekteskapet ikke nyter det samme vernet som det bigamiske ekteskapet i norsk rett. Det vil da foreligge legitime grunner for ikke å anerkjenne det, eventuelt for å oppløse det. En slik endring av familieinnvandringsreglene ville skape et incitament for at familieinnvandring blir søkt for kone nummer én. Risikoen for å få en problematisk sak etter norsk rett vil dermed unngås.

\subsection{Problemer med utlendl. $\S \S 44$ og 45}

Utlendl. $\S 44$ og 45 gjør unntak for rett til oppholdstillatelse basert på foreldreskap mellom norske barn og deres utenlandske forelder dersom det vil føre til at polygame familieforhold etableres i Norge. Utlendl. $§ 44$ gir tillatelse til familiegjenforening mellom norsk barn og barnets mor eller far, men kan etter annet ledd «likevel nektes dersom dette ville lede til at søkeren ville bli gjenforent med en herboende ektefelle som allerede er gift med eller samboer med en annen person her [...]». ${ }^{64}$ Bestemmelsen er en kan-bestemmelse, men det gjøres klart i forarbeidene at bestemmelsen skal forhindre bigamiske forhold: «Annet ledd første punktum skal forhindre at bestemmelsen åpner for bigami.» ${ }^{65}$

Utlendl. § 45 gjelder rett til oppholdstillatelse for mor eller far som skal ha samvær med norsk barn, og har også tilsvarende unntaksbestemmelse i annet ledd. På samme måte som med bestemmelsen i $\S 44$ er formålet her å forhindre at polygame forhold etableres i Norge. ${ }^{66}$

Dette kan føre til det resultat at det bigamiske ekteskapet vil være til hinder for at det første ekteskapet skal danne grunnlag for familieinnvandring. Dette fremstår som ulogisk i og med

\footnotetext{
${ }^{64}$ Resten av bestemmelsen lyder: «Det samme gjelder dersom søkeren og den herboende forelderen ikke er gift på søknadstidspunktet, men det på et tidligere tidspunkt har bestått et bigamt forhold mellom søkeren, den herboende forelderen og dennes nåværende ektefelle eller samboer.» Jeg går ikke nærmere inn på denne delen av bestemmelsen.

${ }^{65}$ Ot.prp. nr. 75 (2006-2007) s. 424. Dette stadfestes også på s. 212 og NOU 2004: 20 s. 406.

${ }^{66}$ Ot.prp. nr. 75 (2006-2007) s. 425.
} 
at det første ekteskapet ikke blir anerkjent selv om det er fullt ut i overensstemmelse med norske rettsgrunnsetninger. Utgangspunktene i norsk internasjonal privatrett snus altså her på hodet, uten at forarbeidene til loven gir noen begrunnelse for denne rettslige løsningen.

Reglene i utlendl. $\S \S 44$ og 45 fremstår som dårlig begrunnet sett i et barneperspektiv og ut fra vernet av familierelasjoner. Den eneste begrunnelsen for reglene er at man ønsker å forhindre etableringen av polygame familier i Norge. En slik begrunnelse overser hensynet til barna siden grunnen til at de ikke vil få gjenforening med moren sin, er at norske myndigheter bevisst har godtatt som gyldig et senere ekteskap som deres far inngikk for så å bruke innvandringsreglene for å hindre de faktiske konsekvenser dersom kone nummer én også kom til landet. Barnas behov for å være sammen med moren sin blir altså et hensyn som overses ved denne reguleringen. Å knytte vilkår til familiegjenforening mellom barn og deres mor til hvorvidt faren har inngått et etterfølgende bigamisk ekteskap, fremstår som urimelig og uproporsjonalt.

Et spørsmål som reiser seg, er hvorvidt retten til familiegjenforening mellom foreldre og barn i det hele tatt bør avhenge av foreldrenes ekteskapelige status. Bør ikke formålet om å unngå at reelt polygame ekteskap skal etablere seg i Norge, søkes oppnådd på andre måter, uten slike uheldige rettslige konsekvenser som typisk vil berøre diskrimineringsvernet og hensynet til barnets beste?

\section{Avslutning}

Det er et tydelig behov for at reguleringen av bigami i norsk rett gjennomgås. Rettstilstanden, hvorvidt utenlandsk inngåtte bigamiske ekteskap skal anerkjennes i Norge og hvilke rettsvirkninger som eventuelt skal følge av dem, er uavklart. Lovgiver har ikke vurdert relevante rettskilder og hensyn i sammenheng. Det er dårlig samsvar mellom de ulike regelverk, og dette kan få uheldige konsekvenser. I utlendingsretten tas det ikke høyde for verken preferansen for det første ekteskapet som har sitt grunnlag i norsk internasjonal privatrett, eller diskrimineringsvernet som gjelder i norsk rett.

\section{Litteratur:}

Blackburn, S. 2004.Women and the state in modern Indonesia. Cambridge: Cambridge University Press

Brooks, T. 2009. The Problem with Polygamy. Philosophical Topics, Vol. 37, No. 2, Global Gender Justice (FALL 2009), s. 109-122. 
Cordero-Moss, G. 2016. «Omgåelse av preseptorisk rett gjennom lovvalg som ugyldighetsgrunn?», kapittel 3 i Hjelmeng, E. (red.), Ugyldighet i privatretten: minnebok for Viggo Hagstrøm, Bergen: Fagbokforlaget, s. 183-205.

Cordes, J. et al. 2010. Hovedlinjer i internasjonal privatrett. Oslo: Cappelen

Eriksen, T.H. 1997. Små steder - store spфrsmål: Innføring i sosialantropologi. Oslo: Universitetsforlaget

Frantzen, T. 2002. Arveoppgjør ved internasjonale ekteskap: Studier av norsk internasjonal privatrett med sarlig vekt på gjenlevende ektefelles rettsstilling. Bergen: Fagbokforlaget Frantzen, T. 2007. «Tiltak mot tvangsekteskap», i Frantzen et al. (red.): Rett og toleranse: Festskrift til Helge Johan Thue. Oslo: Gyldendal akademisk.

Holmøy, V., Lødrup, P. og Asland, J. 2013. Ekteskapsloven med kommentarer: Bind 1. Oslo: Gyldendal Juridisk

Lundgaard, H.P. 2000. Gaarders innføring i internasjonal privatrett: ved Hans Petter Lundgaard. Oslo: Universitetsforlaget.

Lødrup, P. og Sverdrup, T. 2016. Familieretten. 8. utgave. Oslo.

Moss, G.C. 1999. International Commercial Arbitration: Party Autonomy and Mandatory Rules. Oslo: Aschehoug

Strand, V.B. 2012. Diskrimineringsvern og religionsutфvelse: Hvor langt rekker individvernet? Oslo: Gyldendal Juridisk

Thue, H.J., 2002. Internasjonal privatrett: personrett, familierett og arverett. Oslo: Gyldendal akademisk

WLUML, 2006. Knowing our Rights. Women, family, laws and customs in the Muslim world. London: WLUML

Wærstad, T.L. 2016. «Harmonising Human Rights Law and Private International Law through the Ordre Public Reservation: The Example of the Norwegian Regulation of the Recognition of Foreign Divorces». Oslo Law Review, 2016, Issue 1, s. 51-71.

Wærstad, T.L. 2017 a. Protecting Muslim Minority Women's Human Rights at Divorce: Application of the Protection against Discrimination Guarantee in Norwegian Domestic Law, Private International Law and Human Rights Law. Baden-Baden: Nomos

Wærstad, T.L. 2017 b. «Hvordan sikre kvinners diskrimineringsvern i møte med kulturelle praksiser gjennom forbudet mot strukturell diskriminering $\mathrm{i}$ kvinnediskrimineringskonvensjonen (KDK)», i Hartlev et al. 2017: Ketsch me if you canSociale rettigheder og ligestilling: Hyldest til Kirsten Ketscher. København: Karnov Group. 
Fullstendig referanseliste fås ved henvendelse til forfatteren 